\title{
Risk Factors for post-Endoscopic Retrograde Cholangiopancreatography Abdominal Pain in Patients without post-ERCP Pancreatitis
}

\section{Mengjie Chen}

Nanjing Drum Tower Hospital Clinical College of Nanjing Medical University

\section{Ruhua Zheng}

Nanjing Drum Tower Hospital Clinical College of Nanjing Medical University

Jun Cao

Nanjing Drum Tower Clinical College of Nanjing Medical University

\section{Yuling Yao}

Nanjing Drum Tower Hospital Clinical College of Nanjing Medical University

\section{Lei Wang}

Nanjing Drum Tower Hospital Clinical College of Nanjing Medical University

Xiaoping Zou ( $\square$ zouxp@nju.edu.cn )

Nanjing Drum Tower Hospital Clinical College of Nanjing Medical University

\section{Research article}

Keywords: Post-ERCP abdominal pain, Cholangiopancreatography, Endoscopic retrograde, Pancreatitis, Risk factor

Posted Date: July 13th, 2020

DOl: https://doi.org/10.21203/rs.3.rs-40959/v1

License: (9) This work is licensed under a Creative Commons Attribution 4.0 International License. Read Full License

Version of Record: A version of this preprint was published at Hepatobiliary \& Pancreatic Diseases International on December 1st, 2021. See the published version at https://doi.org/10.1016/j.hbpd.2021.12.002. 


\section{Abstract}

Background: Most of the studies on the abdominal pain associated with endoscopic retrograde cholangiopancreatography (ERCP) are aimed at solving the pain during the procedure. Post-ERCP abdominal pain has rarely been investigated冈and few studies have focused on the characteristics and risk factors of post-ERCP abdominal pain without post-endoscopic retrograde cholangiopancreatography pancreatitis (PEP).This study aimed to identify risk factors of post-ERCP abdominal pain without PEP and investigate characteristics of the abdominal pain in non-PEP patients.

Methods: From August 6th, 2019, to January 15th, 2020, data of patients who underwent ERCP were retrospectively collected. The characteristics of the abdominal pain after ERCP were recorded and compared between PEP and non-PEP patients. Multivariate analysis was conducted to identify risk factors of non-PEP abdominal pain.

Results: Data from 616 ERCP procedures were retrospectively investigated in this study, among which $51(8.28 \%)$ patients presented post-ERCP abdominal pain without PEP and $45(7.31 \%)$ patients developed PEP. Multivariate analysis found that 5 risk factors were associated with non-PEP abdominal pain: female gender (OR:2.137), upper abdominal surgery history (OR:1.948), first time ERCP (OR:4.735), elevated serum $\gamma$-glutamyl transferase $(\gamma-\mathrm{GT})$ (OR:2.570) and elevated serum direct bilirubin (DBIL) (OR:2.932). Visual analogue sale (VAS) score of PEP abdominal pain was higher than that of non-PEP pain group $(P=0.05)$. There were no significant differences in the time of the onset of the pain, pain relief time, pain frequency, use of analgesic medicine, hospital stay and mortality between PEP and non-PEP pain group $(P<0.05)$.

Conclusion: This study indicated that female gender, upper abdominal surgery history, first time ERCP, elevated $\gamma$-GT and elevated DBIL were independent risk factors for post-ERCP abdominal pain without PEP. Abdominal pain was severer in PEP patients than non-PEP patients.

\section{Introduction}

Abdominal pain is often observed in patients after endoscopic retrograde cholangiopancreatography (ERCP) procedure, which sometimes indicates the occurrence of complications such as post-ERCP pancreatitis, perforation, or cholangitis. The most common complication with post procedure abdominal pain is acute pancreatitis, which occurs in $3.5 \%-14.7 \%$ of the cases ${ }^{[1,2]}$ and leads to death in $0.1-1.1 \%$ of the patients ${ }^{[2,3]}$. For clinicians, fear of severe complication with abdominal pain may lead to anxiety and excessive treatment. Moreover, post-ERCP pain may influence the satisfaction and mental state of patients.

Most of the researches on the abdominal pain associated with ERCP are aimed at solving the pain during the procedure ${ }^{[4]}$. Post-ERCP abdominal pain is one of the major symptoms of PEP; however, abdominal pain after the procedure also indicates potential occurrence of post-ERCP cholangitis, perforation and 
nonspecific etiology (flatulence, gastric and intestinal spasm, etc.). Few studies have focused on the characteristics and risk factors of post-ERCP abdominal pain without PEP.

Therefore, this study aimed to identify the characteristics and risk factors of post-ERCP abdominal pain without PEP. Differences between abdominal pain with or without PEP were compared so as to guide clinical diagnosis and decision-making.

\section{Methods}

\section{Study design and patients}

In this retrospective study, all patients who underwent ERCP from August 6th, 2019, to January 15th, 2020, at Nanjing Medical University Affiliated Drum Tower Clinical Medical College were included. Exclusion criteria included any of the following: 1) failed operation; 2) missing any of the indicators. The Medical Ethics Committee of Nanjing Medical University Affiliated Drum Tower Clinical Medical College approved this retrospective data only study with waiver of informed consent. The need for individual consent was waived for retrospective cohorts.

\section{Data collection}

The following data were extracted from the medical charts: patient-related (sex, age, surgical history, gastrectomy history, cholecystectomy history, drinking history, smoking history, hypertension, diabetes, coronary heart disease, chronic pancreatitis history, acute pancreatitis history, white blood cells(WBC), hemoglobin $(\mathrm{Hb})$, platelet(PLT), neutrophil percentage(Neut\%), alanine aminotransferase (ALT), aspartate aminotransferase (AST), $\gamma$ - glutamyl transferase $(\gamma-\mathrm{GT})$, total bilirubin(TBIL), direct bilirubin (DBIL), alkaline phosphatase (ALP), albumin (ALB), prothrombin time (PT), history of pancreatic diseases, suspection of sphincter of Oddi dysfunction (SOD), hilar bile duct stricture, distal biliary stricture, diagnosis of common bile duct stone, and adenoma of the duodenal papilla); procedure-related (pre-cut, endoscopic sphincterotomy, pancreatic guidewire passages, biliary stent placement, endoscopic papillary balloon dilatation(EPBD), endoscopic papillary large-balloon dilation(EPLBD), nasobiliary drainage, difficult biliary cannulation (cannulation attempts of duration $>10$ minutes, and/or $>5$ attempts), contrast injection to the pancreatic duct, dilated extrahepatic bile duct, type of papillary orifice, pancreatic duct stenting and operator experience (high grade: >200 ERCP procedures total and/or > 50/year); postoperative outcomes(Visual analogue scale(VAS) score of post-ERCP abdominal pain, time of the onset of post-ERCP pain, pain relief time, pain frequency, use of analgesic medicine, use of protease inhibitors, total hospital stay, hospital stay after ERCP. Indomethacin suppository was given routinely as per the judgment of the operator. If the patient had new or aggravated epigastric pain within 72 hours after procedure, abdominal imaging was routinely performed according to the general situation of the patient, and, if necessary, protease inhibitors or analgesic medicine was given.

\section{Definitions}


PEP is diagnosed with 2 out of 3 diagnostic criteria defined by the Revised Atlanta Classification (pancreatic abdominal pain, three times upper limit of normal elevation of serum lipase, imaging suggestive of pancreatitis). Post-ERCP cholangitis is defined as new onset of fever $\left(>38^{\circ} \mathrm{C}\right.$, lasting over

24 hours) and cholestasis. Post-ERCP perforation is defined with imaging evidence of gas or luminal contents outside of the gastrointestinal tract. Post-ERCP bleeding is diagnosed with hematemesis and/or melena or hemoglobin drop $>2 \mathrm{~g} / \mathrm{dL}$ or bloody fluid from nasobiliary drainage. Severity grading is conformed with ESGE guideline $2019^{[5]}$. Post-ERCP abdominal pain is diagnosed as a new or aggravated upper abdominal pain within 72 hours after ERCP.

\section{Statistical analysis}

The continuous data were dichotomized according to the cut-off value of each indicator based on clinical significance or normal range. Categorical data were expressed as numbers, rates, and percentages and were compared with the chi-square test or Fisher's test. The relevant factors found by univariate analyses $(P<0.15)$ were included in the multivariate logistic regression analysis (forward stepwise regression selection). A receiver operating characteristics (ROC) curve was used to examine the sensitivity and specificity, and the area under the ROC curve (AUC) was used for discrimination.

Propensity score matching was performed to compare the realistic difference between PEP group and non-PEP group with post-ERCP abdominal pain. Prior to propensity matching, $t$ tests or Chi-Square tests were used to assess for differences between groups. PEP group and non-PEP pain group were matched 1:1 on the following variables: age, gender, comorbidities (coronary heart disease, diabetes, hypertension, chronic liver disease, malignant tumors or cancer, chronic pancreatitis), surgery history, operation time, laboratory tests before operation (complete blood count, liver function test, kidney function test, prothrombin time (PT), CA199). McNemar's test was used for binary variables. And a paired Student's ttest or paired-sample test was used for continuous variables. Statistical significance was treated as a pvalue $<0.05$. All data were analyzed using SPSS 25 .

\section{Results}

\section{Characteristics of the patients}

Data of 616 patients who underwent ERCP from August 6, 2019, to January 15, 2020 were retrospectively collected. Among these patients, 45 developed post-ERCP pancreatitis, and 51 presented post-ERCP abdominal pain without PEP, including 11 post-ERCP cholangitis, 1 mild bleeding and 39 nonspecific abdominal pain. The rest 520 patients did not have any abdominal pain after operation. Patients' characteristics between normal group and non-PEP pain group were presented in Table 1.

\section{Univariate analysis}

In the univariate analysis, 14 of 46 patient-related factors and 9 of 23 procedure-related factors were found to be associated with an increased risk of post-ERCP abdominal pain without PEP (Table 1). 
Patient-related risk factors included: female gender, age $<60 \mathrm{yr}$, no hypertension, first time ERCP, no drinking history, normal neut\%, lower $\mathrm{Hb}$, normal ALT, elevated $\gamma$-GT, normal TBIL, elevated DBIL, normal ALP, normal ALB, normal CA199. Procedure-related risk factors included: rectal indomethacin, native papilla, difficult cannulation, pancreatic guidewire passages, contrast injection to the pancreatic duct, absence of EPLBD, absence of brush cytology, absence of biliary stent placement, pancreatic duct stenting.

\section{Multivariate analysis}

Risk factors that reached a p-value cut-off 0.15 or less were used to create the multivariate model. Variables which were considered to be the risk factors according to clinical experience and previous researches were also analyzed. The identified factors were entered into multivariate model (Table 2). Five risk factors were significant by multivariate analysis, three were characteristics of the patients (female gender, first time ERCP, upper abdominal surgery history), and two were preoperative laboratory examinations (elevated serum $\gamma$-GT and DBIL before ERCP) (Figure 2). The Hosmer-Lemeshow goodness of fit test was not significant $(p=0.982)$ at the 0.05 significance level and the $C$-statistic was 0.764 .

\section{Table 2. Multivariate analyses $(\mathrm{C}$-statistic $=\mathbf{0 . 7 6 4 )}$}

\begin{tabular}{|lllll|}
\hline Risk Factors & $\boldsymbol{\beta}$ & Odds Ratio & 95\% Confidence Interval & $\boldsymbol{p}$ value \\
\hline Gender(female) & 0.759 & 2.137 & $1.152-3.962$ & 0.016 \\
\hline Primary ERCP & 1.555 & 4.735 & $1.886-11.889$ & 0.001 \\
\hline Y-GT & 0.944 & 2.570 & $1.299-5.085$ & 0.007 \\
\hline DBIL & 1.076 & 2.932 & $1.356-6.341$ & 0.006 \\
\hline Upper abdominal surgery history & 0.667 & 1.948 & $1.009-3.761$ & 0.047 \\
\hline
\end{tabular}

Y-GT: Y-glutamyl transferase; DBIL: direct bilirubin.

\section{Propensity matching between PEP group and non-PEP pain group}

In order to identify the characteristics of the post-ERCP pain without PEP, PEP group and non-PEP pain group were compared and analysed. Before propensity matching, there were differences between the PEP group and non-PEP pain group in baseline characteristics. With the use of propensity matching, 34 patients with PEP were matched with 34 patients with non-PEP abdominal pain. The baseline characteristics were comparable after propensity matching (Table 3). Characteristics between two groups were similar in the time of the onset of the pain, pain relief time and pain frequency $(P<0.05)$ (Table.4). It showed that pain intensity \expressed as VAS score『of post-ERCP abdominal pain related to PEP was higher than that of non-PEP pain. $(P=0.05)$. There were no significant differences in the use of analgesic medicine, hospital stay and mortality between the two groups. 
Table 4. Characteristics between non-PEP group and PEP group

\begin{tabular}{|llll|}
\hline & $\begin{array}{l}\text { Non-PEP group } \\
\mathbf{n}=34 \square \%\end{array}$ & $\begin{array}{l}\text { PEP group } \\
\mathbf{n}=34 \square \% \square\end{array}$ & $p$ value \\
\hline Total hospital stay (days) & $10.15 \pm 8.894$ & $13.71 \pm 17.85$ & 0.214 \\
\hline Hospital stay after ERCP (days) & $7.38 \pm 8.59$ & $10.56 \pm 13.22$ & 0.244 \\
\hline Mortality & 1 & 0 & 1.000 \\
\hline Time of the onset of pain(hours) & $13.19 \pm 16.44$ & $9.04 \pm 7.76$ & 0.193 \\
\hline VAS score & $3.68 \pm 1.81$ & $4.50 \pm 1.36$ & 0.050 \\
\hline Pain relief time(hours) & $1.98 \pm 3.59$ & $1.39 \pm 2.07$ & 0.412 \\
\hline Pain frequency(times) & $1.41 \pm 1.28$ & $1.60 \pm 1.20$ & 0.524 \\
\hline Analgesic medicine use & 22 & 27 & 0.280 \\
\hline Protease inhibitors use & 13 & 31 & 0.000 \\
\hline
\end{tabular}

\section{Discussion}

Abdominal pain after ERCP is common and is a source of distress to both patient and physician. Occasionally it predicts complications related to the procedure, especially PEP. However, apart from PEP, some postprocedural pain is of other etiology: 1. Post-ERCP cholangitis, typically presenting with fever, jaundice, and abdominal pain, needing use of anti-biotics or repeated ERCP; 2 . Perforation, manifested as severe abdominal and back pain, abdominal tenderness and fever, needing intensive management, even surgery; 3. Nonspecific pain, often resolving in several hours. Several reports considered nonspecific pain may in part relate to bowel insufflation with air ${ }^{[4,6]}$. According to typical clinical symptoms, it is relatively easier to identify perforation, bleeding and cholangitis. Therefore, it is a challenge for early differentiating between the pain of PEP and nonspecific pain. Empirical data on post-ERCP abdominal pain can be used to optimize the information for patients undergoing ERCP. It may contribute to improvement of a patient's tolerance and the practice guidelines of support treatment, because such data enable better preparation of both patients and physician for the procedure.

In our study, 51 non-PEP pain patients consist of 11 mild post-ERCP cholangitis, 1 mild bleeding and 39 nonspecific pain. Our results showed that non-PEP pain was associated with female gender, first time ERCP and upper-abdominal surgery history, as well as patient's elevated pre-ERCP serum $\gamma$-GT and DBIL level. Female gender was found to be the risk factor for post-ERCP abdominal pain without PEP in this study. Tom B. Glomsaker ${ }^{[7]}$ found that female patients demonstrated an increased risk for reporting pain both during and after the ERCP procedure. Though this study did not exclude patients with PEP, this finding is partly in agreement with our result. Patients who underwent ERCP for the first time have a 
higher risk of abdominal pain after ERCP. Essink-Bot et al. ${ }^{[8]}$ found that patients who had undergone previous surveillance endoscopies for Barrett's esophagus experienced less discomfort, pain, and overall burden than patients who underwent upper endoscopy for the first time. They suggested that these previous surveillance endoscopies had resulted in an adaptation to the procedure. Upper-abdominal surgery history may cause postoperative abdominal adhesions and alter anatomy which would increase operative difficulty and probability of postoperative abdominal pain. Karayiannakis et al. ${ }^{[9]}$ reported that adhesions in patients with upper-abdominal surgery occurred more frequently, and were more extensive and denser than those in patients with lower-abdominal surgery. It explains why no significant difference in the history of lower-abdominal surgery or the history of all types of surgery between groups was found in our study. Moreover, our study found that elevated serum $\gamma$-GT and DBIL before the procedure were risk factors for post-ERCP pain. In contrast, elevated serum DBIL was proved to be protective factors for $P E P^{[10]}$, which means that if patients with abnormal DBIL present abdominal pain after ERCP, it is more likely to be other etiology rather than PEP.

Most clinicians would agree that patient satisfaction is of great importance. Patient satisfaction related to the ERCP procedure is related to the patients' experiences of pain during and after the procedure regularly ${ }^{[7]}$. Nonspecific pain after ERCP may be confused with early symptom of complications, which influences clinical treatment and causes patients' postoperative anxiety. After propensity-score matching, we found that the pain intensity related to PEP was more severe than that without PEP $(4.50 \pm 1.36$ vs. $3.68 \pm 1.81, p=0.050)$. Our result was consistent with that of the previous studies. JSGE guideline for post-ERCP pancreatitis ${ }^{[11]}$ showed that strong abdominal pain indicates a high probability of PEP. Hauser G er al. ${ }^{[12]}$ found a threshold VAS score of 5 was strongly associated with the occurrence of PEP. They suggested that the VAS scores for abdominal pain appear to have an excellent diagnostic value for predicting both the presence and absence of PEP. Thus, VAS score may help distinguishing these two types of pain. For this study, it was reasonable to found protease inhibitors were used more frequently in PEP cases. The use of analgesic medicine was similar between PEP group and non-PEP pain group. Clinicians tended to give analgesic medicine rather than protease inhibitors to relief pain firstly in our study. It indicated that non-PEP pain especially nonspecific pain may lead to analgesic abuse.

Our study has limitations. This is a retrospective, observational study and hence suffers from potential selection and ascertainment bias despite propensity-score matching. Larger sample sizes or prospective studies are necessary to reduce biases.

\section{Conclusion}

In conclusion, our study indicated that female gender, first time ERCP, elevated serum $\gamma$-GT, elevated serum DBIL and upper abdominal surgery history were independent risk factors for post-ERCP abdominal pain without PEP. Characteristics of post-ERCP pain were different in VAS score between PEP patients and non-PEP pain patients. These findings may contribute to the relief of patients' discomfort and dissatisfaction and therefore improve the quality of ERCP procedures and patient management. 


\section{Abbreviations}

ERCP

Endoscopic retrograde cholangiopancreatography; PEP:Post-ERCP pancreatitis; VAS:Visual analogue sale; OR:Odds ratio; EPBD:Endoscopic papillary balloon dilatation; EPLBD:Endoscopic papillary largeballoon dilation(EPLBD); AUC:Area under the curve; ROC:Receiver operating characteristic curve

\section{Declarations}

\section{Ethics approval and consent to participate}

The study was approved by the Ethical Committee at Nanjing Drum Tower Hospital Affiliated to Nanjing University Medical School. The Ethical Committee at Nanjing Drum Tower Hospital Affiliated to Nanjing University Medical School approved the waiver of consent.

\section{Consent for publication}

Not applicable.

\section{Availability of data and materials}

The data set analyzed in the current study cannot be opened to public because patients' privacy must be protected and IRB does not permit to do so. However, data are available from the author upon reasonable request.

\section{Competing interests}

The authors declare that they have no competing interests.

\section{Funding}

This study was supported by National Natural Science Foundation of China (No.81871947)

\section{Authors' contributions}

$\mathrm{XZ}$ and LW designed the research and the study concept; $\mathrm{MC}$ and $\mathrm{RZ}$ contributed to analysis and interpretation of data; $\mathrm{JC}$ and $\mathrm{YY}$ contributed to the acquisition of data. $\mathrm{MC}$ and $\mathrm{RZ}$ wrote the paper. $\mathrm{XZ}$ and LW supervised the study; all of the co-authors conducted a critical revision of the manuscript for important intellectual content. All authors read and approved the final version of the manuscript.

\section{Acknowledgements}


Not applicable.

\section{References}

1. Dumonceau JM, Andriulli A, Elmunzer BJ, et al. Prophylaxis of post-ERCP pancreatitis: European Society of Gastrointestinal Endoscopy (ESGE) Guideline - updated June 2014. Endoscopy. 2014;46(9):799-815.

2. Kochar B, Akshintala VS, Afghani E, et al. Incidence, severity, and mortality of post-ERCP pancreatitis: a systematic review by using randomized, controlled trials. Gastrointest Endosc. 2015;81(1):1439.e149.

3. Heitman SJ. ERCP and Mortality. Gastroenterology Hepatology. 2014;10(11):752-4.

4. Bretthauer M, Seip B, Aasen S, et al. Carbon dioxide insufflation for more comfortable endoscopic retrograde cholangiopancreatography: a randomized, controlled, double-blind trial. Endoscopy. 2007;39(1):58-64.

5. Dumonceau J-M, Kapral C, Aabakken L, et al. ERCP-related adverse events: European Society of Gastrointestinal Endoscopy (ESGE) Guideline. Endoscopy. 2019;52(02):127-49.

6. Maple JT, Keswani RN, Hovis RM, et al. Carbon dioxide insufflation during ERCP for reduction of postprocedure pain: a randomized, double-blind, controlled trial. Gastrointest Endosc. 2009;70(2):278-83.

7. Glomsaker TB, Hoff G, Kvaløy JT, et al. Patient-reported outcome measures after endoscopic retrograde cholangiopancreatography: a prospective, multicentre study. Scand J Gastroenterol. 2013;48(7):868-76.

8. Essink-Bot M-L, Kruijshaar ME, Bac DJ, et al. Different perceptions of the burden of upper GI endoscopy: an empirical study in three patient groups. Qual Life Res. 2007;16(8):1309-18.

9. Botaitis S, Simopoulos C, Karayiannakis AJ, et al. Laparoscopic cholecystectomy in patients with previous upper or lower abdominal surgery. Surg Endosc. 2004;18(1):97-101.

10. Freeman ML, DiSario JA, Nelson DB, et al. Risk factors for post-ERCP pancreatitis: a prospective, multicenter study. Gastrointest Endosc. 2001;54(4):425-34.

11. Mine T, Morizane T, Kawaguchi Y, et al. Clinical practice guideline for post-ERCP pancreatitis. J Gastroenterol. 2017;52(9):1013-22.

12. Hauser G, Blažević l, Salkić N, et al. Diclofenac sodium versus ceftazidime for preventing pancreatitis after endoscopic retrograde cholangiopancreatography: a prospective, randomized, controlled trial. Surg Endosc. 2016;31(2):602-10.

\section{Tables}

Table 1. Univariate analyses 


\begin{tabular}{|c|c|c|c|}
\hline & Normal group $[\% \square$ & Non-PEP pain group $[\% \square$ & $p$ \\
\hline Gender(female) & 213/520ロ40.96ロ & $35 / 51 \square 68.63 \square$ & 0.003 \\
\hline Age (<60yr) & $193 / 520 \llbracket 37.12 \square$ & $28 / 51 \square 54.90 \square$ & 0.016 \\
\hline Past history & $358 / 520 \square 68.85 \square$ & $32 / 51 \square 62.75 \square$ & 0.430 \\
\hline Hypertension & $196 / 520 \square 37.69 \square$ & $12 / 51 \square 23.53 \square$ & 0.048 \\
\hline Coronary heart disease & $34 / 520 \square 6.54 \square$ & $2 / 51 \llbracket 3.92 \square$ & 0.666 \\
\hline Diabetes & 94/520ロ18.08ロ & 9/51ロ17.65ロ & 1.000 \\
\hline Hepatitis & 43/520ロ8.27ロ & 6/51ロ11.76ロ & 0.556 \\
\hline Tuberculosis & $6 / 520 \square 1.15 \square$ & 2/51₫3.92₫ & 0.155 \\
\hline Malignancy & $15 / 520 \square 2.88 \square$ & 1/51ロ1.96ロ & 1.000 \\
\hline Acute pancreatitis & $16 / 520 \square 3.08 \square$ & $1 / 51 \square 1.96 \square$ & 0.987 \\
\hline Chronic pancreatitis & $18 / 520 \square 3.46 \square$ & $2 / 51 \llbracket 3.92 \square$ & 1.000 \\
\hline Cirrhosis & $24 / 520 \square 4.62 \square$ & $0 / 51 \square 0 \square$ & 0.229 \\
\hline Fatty liver & 28/520ロ5.38ロ & $0 / 51 \square 0 \square$ & 0.174 \\
\hline Allergy history & $41 / 520 \square 7.88 \square$ & 6/51ロ11.76ロ & 0.487 \\
\hline Transfusion history & $22 / 520 \square 4.23 \square$ & 1/51ı1.96凸 & 0.679 \\
\hline Surgical history & $452 / 520 \square 86.92 \square$ & $43 / 51 \square 84.31 \square$ & 0.665 \\
\hline First time ERCP & $381 / 520 \square 73.27 \square$ & 44/51ロ86.27ロ & 0.044 \\
\hline Upper abdominal surgery history & $264 / 520 \square 50.77 \square$ & $30 / 51 \square 58.82 \square$ & 0.306 \\
\hline Lower abdominal surgery history & $104 / 520 \square 20.00 \square$ & 8/51ロ15.69ロ & 0.474 \\
\hline Orthopedic surgery & $22 / 520 \square 4.23 \square$ & 1/51ロ1.96ロ & 0.679 \\
\hline Cardiothoracic surgery & $32 / 520 \square 6.15 \square$ & $2 / 51 \square 3.92 \square$ & 0.739 \\
\hline Head and neck surgery & $22 / 520 \square 4.23 \square$ & $1 / 51 \square 1.96 \square$ & 0.679 \\
\hline Gastrectomy history & $14 / 520 \square 2.69 \square$ & $2 / 51 \square 3.92 \square$ & 0.530 \\
\hline Trauma history & $25 / 520 \square 4.81 \square$ & 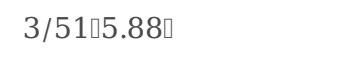 & 1.000 \\
\hline Smoking history & 96/520ロ18.46ロ & 8/51ロ15.69ロ & 0.708 \\
\hline Drinking history & 69/520ロ13.27ロ & $2 / 51 \square 3.92 \square$ & 0.071 \\
\hline $\mathrm{WBC} \square \leq 9.5 \square$ & $442 / 520 \square 85.00 \square$ & $46 / 51 \square 90.20 \square$ & 0.407 \\
\hline $\mathrm{N}$ rate $\square \leq 75 \% \square$ & $375 / 520 \square 72.12 \square$ & $42 / 51 \llbracket 82.35 \square$ & 0.068 \\
\hline $\mathrm{Hb} \square \leq 120 \square$ & $307 / 520 \square 59.04 \square$ & $37 / 51 \square 72.55 \square$ & 0.072 \\
\hline PLT ( $\geq 125 \square$ & $416 / 520 \square 80.00 \square$ & $44 / 51 \square 86.27 \square$ & 0.355 \\
\hline $\operatorname{ALT}(\leq 40)$ & $217 / 520 \square 41.73 \square$ & $31 / 51 \square 60.78 \square$ & 0.011 \\
\hline $\operatorname{AST}(\leq 40)$ & $272 / 520 \square 52.31 \square$ & $30 / 51 \square 58.82 \square$ & 0.383 \\
\hline$\gamma-\mathrm{GT}(>35)$ & 433/520ロ83.27ロ & $30 / 51 \square 58.82 \square$ & 0.000 \\
\hline $\mathrm{BIL}(\leq 28)$ & $281 / 520 \square 54.04 \square$ & 39/51ロ76.47ロ & 0.003 \\
\hline DBIL (>10) & $261 / 520 \square 50.19 \square$ & 10/51ロ19.61ם & 0.000 \\
\hline $\operatorname{ALP}(\leq 185)$ & 313/520ロ60.19ם & 40/51ロ78.43ロ & 0.015 \\
\hline $\operatorname{ALB}(\geq 40)$ & $128 / 520 \llbracket 24.62 \square$ & 19/51₫37.25ロ & 0.064 \\
\hline $\mathrm{PT}(\leq 15)$ & $482 / 520 \square 92.69 \square$ & $50 / 51 \square 98.04 \square$ & 0.249 \\
\hline AMY $(\leq 110)$ & 360/520ロ69.23ロ & 34/51ロ66.67ロ & 0.751 \\
\hline CA199 ( $\leq 27)$ & 326/520ロ62.69ロ & 40/51ロ78.43ロ & 0.031 \\
\hline Pancreatic diseases & $44 / 520 \square 8.46 \square$ & 7/51ロ13.73ロ & 0.317 \\
\hline Common bile duct stone & 338/520匹65.00ロ & $32 / 51 \square 62.75 \square$ & 0.760 \\
\hline Hilar bile duct stricture & $66 / 520 \square 12.69 \square$ & 3/51प5.88ロ & 0.182 \\
\hline Distal biliary stricture & $94 / 520 \square 18.08 \square$ & 8/51ロ15.69ロ & 0.710 \\
\hline
\end{tabular}

Page 10/15 


\begin{tabular}{|c|c|c|c|}
\hline SOD & 2/520ロ0.38ロ & $1 / 51 \square 1.96 \square$ & 0.245 \\
\hline Duodenal papilla carcinoma & $12 / 520 \square 2.31 \square$ & 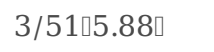 & 0.287 \\
\hline Operator experience (high grade) & $231 / 520 \square 44.42 \square$ & $23 / 51 \square 45.10 \square$ & 1.000 \\
\hline Operative time (<60min) & 472/520ロ90.77ロ & $50 / 51 \square 98.04 \square$ & 0.132 \\
\hline Indomethacin & 8/520ロ1.54ロ & 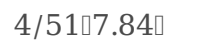 & 0.013 \\
\hline Native orifice & 350/520ロ67.31ם & $40 / 51 \square 78.43 \square$ & 0.116 \\
\hline Peri-diverticular papilla & $108 / 520 \square 20.77 \square$ & 8/51ロ15.69ロ & 0.468 \\
\hline Intra-diverticular papilla & $15 / 520 \square 2.88 \square$ & $2 / 51 \square 3.92 \square$ & 1.000 \\
\hline Difficult biliary cannulation & $51 / 520 \square 9.81 \square$ & 9/51ロ17.65ロ & 0.093 \\
\hline Pancreatic guidewire passages & $176 / 520 \square 33.85 \square$ & $25 / 51 \square 49.02 \square$ & 0.033 \\
\hline Contrast injection to the pancreatic duct & 83/520ロ15.96ロ & $13 / 51 \square 25.49 \square$ & 0.114 \\
\hline Dilated extrahepatic bile duct & $403 / 520 \square 77.50 \square$ & 39/51ם76.47ロ & 1.000 \\
\hline Papilla opening & 338/520ロ65.00ロ & $33 / 51 \square 64.71 \square$ & 1.000 \\
\hline EST & $281 / 520 \square 54.04 \square$ & $31 / 51 \square 60.78 \square$ & 0.380 \\
\hline EPBD & $58 / 520 \square 11.15 \square$ & 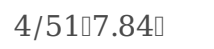 & 0.502 \\
\hline EPLBD & 103/520ロ19.81口 & 5/51₫9.80ロ & 0.092 \\
\hline Pre-cut & $21 / 520 \square 4.04 \square$ & $4 / 51 \square 7.84 \square$ & 0.364 \\
\hline Titanium clip & $30 / 520 \square 5.77 \square$ & $2 / 51 \square 3.92 \square$ & 0.819 \\
\hline Stone extraction & 326/520匹62.69ロ & $32 / 51 \square 62.75 \square$ & 1.000 \\
\hline Nasobiliary drainage & 339/520ロ65.19ם & $38 / 51 \square 74.51 \square$ & 0.216 \\
\hline Bile duct brush & $57 / 520 \square 10.96 \square$ & 2/51₫3.92₫ & 0.148 \\
\hline IDUS & $26 / 520 \square 5.00 \square$ & $0 / 51 \square 0 \square$ & 0.200 \\
\hline Spyglass & $11 / 520 \square 2.12 \square$ & 0/51ロ0凸 & 0.611 \\
\hline Biliary stent placement & $118 / 520 \llbracket 22.69 \square$ & 5/51₫9.80ロ & 0.048 \\
\hline Pancreatic duct stenting & $129 / 520 \square 24.81 \square$ & $19 / 51 \square 37.25 \square$ & 0.065 \\
\hline Hyperamylasemia & $283 / 520 \square 54.42 \square$ & $28 / 51 \square 54.90 \square$ & 1.000 \\
\hline Postoperative $\mathrm{WBC} \square \leq 9.5 \square$ & $71 / 520 \square 13.65 \square$ & 8/51ロ15.69ロ & 0.832 \\
\hline Postoperative $\mathrm{N}$ rate $\square \leq 75 \% \square$ & $223 / 520 \square 42.88 \square$ & $24 / 51 \square 47.06 \square$ & 0.657 \\
\hline Postoperative fever & $122 / 520 \llbracket 23.46 \square$ & $13 / 51 \square 25.49 \square$ & 0.863 \\
\hline Antibiotic after procedure & $220 / 520 \square 42.31 \square$ & $17 / 51 \square 33.33 \square$ & 0.236 \\
\hline Postoperative septic shock & $7 / 520 \square 1.35 \square$ & 1/51ธ1.96凸 & 0.529 \\
\hline Postoperative hemorrhage & $10 / 520 \square 1.92 \square$ & 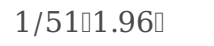 & 1.000 \\
\hline Post-ERCP cholangitis & $114 / 520 \square 21.92 \square$ & $11 / 51 \square 21.57 \square$ & 1.000 \\
\hline Nonspecific abdominal pain & l & 39/51ロ76.47ロ & I \\
\hline Operation for adverse effects & $1 / 520 \sqcap 0.19 \square$ & 0/51ロ0॰ & 1.000 \\
\hline Protease inhibitors after procedure & $165 / 520 \square 31.73 \square$ & $21 / 51 \square 41.18 \square$ & 0.210 \\
\hline
\end{tabular}

PEP: post-ERCP pancreatitis; WBC: white blood cells; Hb: hemoglobin; PLT: platelet; ALT: alanine aminotransferase; AST: aspartate aminotransferase; $\gamma$-GT: $\gamma$-glutamyl transferase; BIL: total bilirubin; DBIL: direct bilirubin; ALP: alkaline phosphatase; ALB: albumin; PT: prothrombin time; AMY: serum amylase; SOD: superoxide dismutase; EST: endoscopic sphincterotomy; EPBD: endoscopic papillary balloon dilation; EPLBD: endoscopic papillary large-balloon dilation

Table 3. Baseline characteristics and procedure characteristics before and after Propensity matching 


\begin{tabular}{|c|c|c|c|c|c|c|}
\hline \multirow[b]{2}{*}{ Variables } & \multicolumn{2}{|c|}{ Before matching } & \multicolumn{4}{|c|}{ After matching } \\
\hline & $\begin{array}{l}\text { Pain without PEP } \\
\mathrm{n}=510 \% \square\end{array}$ & $\begin{array}{l}\text { Pain with PEP } \\
n=45 \square \% \square\end{array}$ & $P$ value & $\begin{array}{l}\text { Pain without PEP } \\
\mathrm{n}=340 \% \square\end{array}$ & $\begin{array}{l}\text { Pain with PEP } \\
\mathrm{n}=34 \square \% \square\end{array}$ & $P$ value \\
\hline Gender(female) & $32 \square 62.75 \square$ & $18 \square 40.00 \square$ & 0.040 & $18 \square 52.94 \square$ & $15 \square 44.12 \square$ & 0.628 \\
\hline $\operatorname{Age}(<60$ yr $)$ & $23 \llbracket 45.10 \square$ & $24 \llbracket 53.33 \square$ & 0.540 & $20 \square 58.82 \square$ & $17 \square 50.00 \square$ & 0.627 \\
\hline Past history & $32 \square 62.75 \square$ & $28 \square 62.22 \square$ & 0.562 & $21 \square 61.76 \square$ & $23 \square 67.65 \square$ & 0.800 \\
\hline Hypertension & $12 \llbracket 23.53 \square$ & $10 \llbracket 22.22 \square$ & 1.000 & $6 \square 17.65 \square$ & $9 \llbracket 26.47 \square$ & 0.560 \\
\hline Coronary heart disease & $2 \llbracket 3.92 \square$ & $1 \llbracket 2.22 \square$ & 1.000 & $1 \square 2.94 \square$ & $1 \square 2.94 \square$ & 1.000 \\
\hline Diabetes & $9 \square 17.65 \square$ & $4 \llbracket 8.89 \square$ & 0.246 & $6 \square 17.65 \square$ & $4 \square 11.76 \square$ & 0.734 \\
\hline Hepatitis & $6 \square 11.76 \square$ & $3 \square 6.67 \square$ & 0.495 & $4 \llbracket 11.76 \square$ & $2 \square 5.88 \square$ & 0.673 \\
\hline Tuberculosis & $2 \square 3.92 \square$ & $0 \square 0 \square$ & 0.497 & $0 \square 0 \square$ & $0 \square 0 \square$ & l \\
\hline Malignancy & $1 \square 1.96 \square$ & $1 \llbracket 2.22 \square$ & 1.000 & $1 \llbracket 2.94 \square$ & $1 \llbracket 2.94 \square$ & 1.000 \\
\hline Acute pancreatitis & $1 \llbracket 1.96 \square$ & $1 \square 2.22 \square$ & 1.000 & $1 \square 2.94 \square$ & $1 \square 2.94 \square$ & 1.000 \\
\hline Chronic pancreatitis & $2 \square 3.92 \square$ & $2 \square 4.44 \square$ & 1.000 & $2 \square 5.88 \square$ & $1 \square 2.94 \square$ & 1.000 \\
\hline Cirrhosis & $0 \square 0 \square$ & $1 \square 2.22 \square$ & 0.469 & $0 \square 0 \square$ & $0 \square 0 \square$ & l \\
\hline Fatty liver & $0 \square 0 \square$ & $2 \square 4.44 \square$ & 0.217 & $0 \square 0 \square$ & $0 \square 0 \square$ & l \\
\hline Allergy history & $6 \square 11.76 \square$ & $6 \square 13.33 \square$ & 1.000 & $6 \square 17.65 \square$ & $6 \square 17.65 \square$ & 1.000 \\
\hline Transfusion history & $1 \square 1.96 \square$ & $2 \llbracket 4.44 \square$ & 0.598 & $1 \llbracket 2.94 \square$ & $2 \square 5.88 \square$ & 1.000 \\
\hline Surgical history & $43 \llbracket 84.31 \square$ & $42 \square 93.33 \square$ & 0.209 & $29 \llbracket 85.29 \square$ & $32 \square 94.12 \square$ & 0.427 \\
\hline Primary ERCP & $44 \llbracket 86.27 \square$ & $37 \llbracket 82.22 \square$ & 0.779 & $27 \square 79.41 \square$ & $27 \square 79.41 \square$ & 1.000 \\
\hline Upper abdominal surgery history & $30 \llbracket 58.82 \square$ & $19 \square 42.22 \square$ & 0.152 & $24 \square 70.59 \square$ & $16 \square 47.06 \square$ & 0.084 \\
\hline Lower abdominal surgery history & $8 \square 15.69 \square$ & $7 \square 15.56 \square$ & 1.000 & $4 \llbracket 11.76 \square$ & $4 \square 11.76 \square$ & 1.000 \\
\hline Orthopedic surgery & $1 \square 1.96 \square$ & $2 \square 4.44 \square$ & 0.598 & $0 \square 0 \square$ & $2 \square 5.88 \square$ & 0.493 \\
\hline Cardiothoracic surgery & $2 \llbracket 3.92 \square$ & $1 \llbracket 2.22 \square$ & 1.000 & $1 \llbracket 2.94 \square$ & $1 \square 2.94 \square$ & 1.000 \\
\hline Head and neck surgery & $1 \square 1.96 \square$ & $0 \square 0 \square$ & 1.000 & $0 \square 0 \square$ & $0 \square 0 \square$ & l \\
\hline Gastrectomy history & $3 \square 5.88 \square$ & $2 \llbracket 4.44 \square$ & 1.000 & $2 \llbracket 5.88 \square$ & $2 \square 5.88 \square$ & 1.000 \\
\hline Trauma history & $3 \square 5.88 \square$ & $3 \square 6.67 \square$ & 1.000 & $2 \square 5.88 \square$ & $3 \llbracket 8.82 \square$ & 1.000 \\
\hline Smoking history & $8 \square 15.69 \square$ & $10 \square 22.22 \square$ & 0.444 & $7 \llbracket 20.59 \square$ & $9 \llbracket 26.47 \square$ & 0.776 \\
\hline Drinking history & $2 \llbracket 3.92 \square$ & $5 \square 11.11 \square$ & 0.247 & $1 \square 2.94 \square$ & $3 \llbracket 8.82 \square$ & 0.614 \\
\hline $\mathrm{WBC} \square \leq 9.5 \square$ & $5 \square 9.80 \square$ & $5 \square 11.11 \square$ & 1.000 & $5 \square 14.71 \square$ & $4 \llbracket 11.76 \square$ & 1.000 \\
\hline $\mathrm{N}$ rate $\leq \mathbf{5} \%$ $\square$ & $8 \square 15.69 \square$ & $5 \square 11.11 \square$ & 0.564 & $6 \square 17.65 \square$ & $4 \square 11.76 \square$ & 0.734 \\
\hline $\mathrm{Hb} \square \leq 120 \square$ & $14 \square 27.45 \square$ & $8 \square 17.78 \square$ & 0.333 & $11 \square 32.35 \square$ & $6 \square 17.65 \square$ & 0.262 \\
\hline PLT $(\geq 125 \square$ & $7 \llbracket 13.73 \square$ & $5 \square 11.11 \square$ & 0.765 & $1 \square 2.94 \square$ & $4 \llbracket 11.76 \square$ & 0.356 \\
\hline $\operatorname{ALT}(\leq 40)$ & $20 \llbracket 39.22 \square$ & $26 \square 57.78 \square$ & 0.101 & $11 \square 32.35 \square$ & $17 \square 50.00 \square$ & 0.218 \\
\hline AST $(\leq 40)$ & $21 \square 41.18 \square$ & $21 \llbracket 46.67 \square$ & 0.681 & $12 \square 35.29 \square$ & $12 \square 35.29 \square$ & 1.000 \\
\hline$\gamma$-GT $(>35)$ & $21 \square 41.18 \square$ & $13 \square 28.89 \square$ & 0.285 & $15 \square 44.12 \square$ & $13 \square 38.24 \square$ & 0.806 \\
\hline $\mathrm{BIL}(\leq 28)$ & $12 \llbracket 23.53 \square$ & $15 \square 33.33 \square$ & 0.364 & $8 \llbracket 23.53 \square$ & $7 \llbracket 20.59 \square$ & 1.000 \\
\hline DBIL $(>10)$ & $41 \square 80.39 \square$ & $30 \square 66.67 \square$ & 0.163 & $27 \square 79.41 \square$ & $27 \square 79.41 \square$ & 1.000 \\
\hline $\operatorname{ALP}(\leq 185)$ & $11 \square 21.57 \square$ & $15 \square 33.33 \square$ & 0.251 & 8ロ23.53ロ & $8 \llbracket 23.53 \square$ & 1.000 \\
\hline ALB $(\geq 40)$ & $32 \square 62.75 \square$ & $23 \square 51.11 \square$ & 0.535 & $22 \square 64.71 \square$ & $18 \square 52.94 \square$ & 0.460 \\
\hline $\mathrm{PT}(\leq 15)$ & $50 \square 98.04 \square$ & $43 \square 95.56 \square$ & 0.598 & 33ロ97.06ロ & $33 \square 97.06 \square$ & 1.000 \\
\hline CA199 $(\leq 27)$ & $11 \square 21.57 \square$ & $15 \square 33.33 \square$ & 0.251 & $7 \llbracket 20.59 \square$ & $11 \square 32.35 \square$ & 0.410 \\
\hline Pancreatic diseases & $7 \square 13.73 \square$ & $6 \square 13.33 \square$ & 1.000 & $6 \square 17.65 \square$ & $6 \square 17.65 \square$ & 1.000 \\
\hline Common bile duct stone & $32 \square 62.75 \square$ & $26 \square 57.78 \square$ & 0.679 & $19 \square 55.88 \square$ & $19 \square 55.88 \square$ & 1.000 \\
\hline Hilar bile duct stricture & $3 \square 5.88 \square$ & $4 \llbracket 8.89 \square$ & 0.702 & $2 \llbracket 5.88 \square$ & $2 \square 5.88 \square$ & 1.000 \\
\hline Distal biliary stricture & $8 \square 15.69 \square$ & 8ロ17.78凸 & 1.000 & $7 \llbracket 20.59 \square$ & $6 \square 17.65 \square$ & 1.000 \\
\hline
\end{tabular}




\begin{tabular}{|c|c|c|c|c|c|c|}
\hline SOD & $1 \square 1.96 \square$ & $0 \square 0 \square$ & 1.000 & $1 \square 2.94 \square$ & $0 \square 0 \square$ & 1.000 \\
\hline Duodenal papilla carcinoma & $3 \square 5.88 \square$ & $3 \llbracket 6.67 \square$ & 1.000 & $1 \square 2.94 \square$ & $3 \square 8.82 \square$ & 0.614 \\
\hline Operator experience (high grade) & $23 \llbracket 45.10 \square$ & $22 \llbracket 48.89 \square$ & 0.838 & $17 \square 50.00 \square$ & $18 \square 52.94 \square$ & 1.000 \\
\hline Operative time & $33.69 \pm 16.53$ & $44.69 \pm 25.10$ & 0.015 & $37.00 \pm 17.54$ & $42.24 \pm 18.22$ & 0.232 \\
\hline Cannulation time & $2.89 \pm 3.61$ & $6.86 \pm 11.77$ & 0.034 & $3.26 \pm 3.95$ & $5.29 \pm 8.29$ & 0.204 \\
\hline Native orifice & $40 \square 78.43 \square$ & $39 \llbracket 86.67 \square$ & 0.422 & $25 \square 73.53 \square$ & $29 \square 85.29 \square$ & 0.369 \\
\hline Peri-diverticular papilla & $8 \square 15.69 \square$ & $16 \square 35.56 \square$ & 0.034 & $6 \square 17.65 \square$ & $11 \square 32.35 \square$ & 0.262 \\
\hline Intra-diverticular papilla & $2 \llbracket 3.92 \square$ & $1 \square 2.22 \square$ & 1.000 & $1 \square 2.94 \square$ & $1 \square 2.94 \square$ & 1.000 \\
\hline Cannulation frequency & $2.71 \pm 2.17$ & $3.96 \pm 5.257$ & 0.123 & $2.76 \pm 2.24$ & $4.03 \pm 5.82$ & 0.241 \\
\hline Difficult biliary cannulation & $9 \square 17.65 \square$ & $12 \llbracket 26.67 \square$ & 0.329 & $7 \square 20.59 \square$ & $8 \square 23.53 \square$ & 1.000 \\
\hline Pancreatic guidewire passages & $25 \square 49.02 \square$ & $26 \square 57.78 \square$ & 0.419 & $20 \square 58.82 \square$ & $21 \square 61.76 \square$ & 1.000 \\
\hline Contrast injection to the pancreatic duct & $13 \square 25.49 \square$ & $13 \llbracket 28.89 \square$ & 0.819 & $11 \square 32.35 \square$ & $12 \llbracket 35.29 \square$ & 1.000 \\
\hline Frequency of pancreatic guidewire passages & $0.78 \pm 0.94$ & $1.16 \pm 1.61$ & 0.165 & $0.88 \pm 0.88$ & $0.97 \pm 1.03$ & 0.705 \\
\hline Dilated extrahepatic bile duct & $39 \square 76.47 \square$ & $28 \square 62.22 \square$ & 0.181 & $24 \square 70.59 \square$ & $18 \square 52.94 \square$ & 0.212 \\
\hline Papilla opening & $33 \square 64.71 \square$ & $3 \square 6.67 \square$ & 0.387 & $20 \square 58.82 \square$ & $23 \llbracket 67.65 \square$ & 0.615 \\
\hline EST & $31 \square 60.78 \square$ & $30 \square 66.67 \square$ & 0.671 & $19 \square 55.88 \square$ & $20 \square 58.82 \square$ & 1.000 \\
\hline EPBD & $4 \llbracket 7.84 \square$ & $6 \square 13.33 \square$ & 0.586 & $2 \square 5.88 \square$ & $6 \square 17.65 \square$ & 0.259 \\
\hline EPLBD & $5 \square 9.80 \square$ & $8 \square 17.78 \square$ & 0.371 & $5 \square 14.71 \square$ & $7 \square 20.59 \square$ & 0.752 \\
\hline Pre-cut & $4 \square 7.84 \square$ & $4 \llbracket 8.89 \square$ & 1.000 & $4 \square 11.76 \square$ & $2 \square 5.88 \square$ & 0.673 \\
\hline Titanium clip & $2 \llbracket 3.92 \square$ & 3ロ6.67ロ & 0.663 & $1 \llbracket 2.94 \square$ & $3 \square 8.82 \square$ & 0.614 \\
\hline Stone extraction & $32 \llbracket 62.75 \square$ & $27 \square 60.00 \square$ & 0.835 & $19 \square 55.88 \square$ & $20 \square 58.82 \square$ & 1.000 \\
\hline Nasobiliary drainage & $38 \square 74.51 \square$ & $27 \square 60.00 \square$ & 0.189 & $26 \square 76.47 \square$ & $20 \square 58.82 \square$ & 0.164 \\
\hline Bile duct brush & $2 \square 3.92 \square$ & $5 \square 11.11 \square$ & 0.247 & $0 \square 0 \square$ & $3 \square 8.82 \square$ & 0.239 \\
\hline IDUS & $0 \square 0 \square$ & $2 \llbracket 4.44 \square$ & 0.217 & $0 \square 0 \square$ & $1 \square 2.94 \square$ & 1.000 \\
\hline Spyglass & $0 \square 0 \square$ & $1 \square 2.22 \square$ & 0.469 & $0 \square 0 \square$ & $1 \square 2.94 \square$ & 1.000 \\
\hline Biliary stent placement & $5 \square 9.80 \square$ & $5 \square 11.11 \square$ & 1.000 & $4 \square 11.76 \square$ & $3 \square 8.82 \square$ & 1.000 \\
\hline Pancreatic duct stenting & $19 \llbracket 37.25 \square$ & $18 \square 40.00 \square$ & 0.835 & $15 \square 44.12 \square$ & $15 \square 44.12 \square$ & 1.000 \\
\hline Hyperamylasemia & $28 \square 54.90 \square$ & $44 \square 97.78 \square$ & 0.000 & $19 \square 55.88 \square$ & $33 \llbracket 97.06 \square$ & 0.000 \\
\hline Postoperative $\mathrm{WBC} \square \leq 9.5 \square$ & $8 \square 15.69 \square$ & $17 \square 37.78 \square$ & 0.019 & $8 \square 23.53 \square$ & $11 \square 32.35 \square$ & 0.590 \\
\hline Postoperative $N$ rate $\llbracket \leq 75 \% \square$ & $24 \llbracket 47.06 \square$ & $36 \square 80.00 \square$ & 0.001 & $21 \square 61.76 \square$ & $26 \square 76.47 \square$ & 0.294 \\
\hline Postoperative fever & $13 \square 25.49 \square$ & $23 \square 51.11 \square$ & 0.012 & $11 \square 32.35 \square$ & $14 \llbracket 41.18 \square$ & 0.615 \\
\hline Antibiotic after procedure & $17 \square 33.33 \square$ & $25 \square 55.56 \square$ & 0.023 & $12 \square 35.29 \square$ & $17 \square 50.00 \square$ & 0.327 \\
\hline Postoperative septic shock & $1 \square 1.96 \square$ & $3 \square 6.67 \square$ & 0.338 & $0 \square 0 \square$ & $2 \square 5.88 \square$ & 0.439 \\
\hline Postoperative hemorrhage & $1 \square 1.96 \square$ & $0 \square 0 \square$ & 1.000 & $0 \square 0 \square$ & $0 \square 0 \square$ & l \\
\hline Post-ERCP cholangitis & $11 \square 21.57 \square$ & $19 \llbracket 41.30 \square$ & 0.046 & $9 \square 26.47 \square$ & $10 \square 29.41 \square$ & 1.000 \\
\hline nonspecific abdominal pain & $39 \square 76.47 \square$ & l & / & $25 \square 73.52 \square$ & I & l \\
\hline Operation for adverse effects & $0 \square 0 \square$ & $0 \square 0 \square$ & l & $0 \square 0 \square$ & $0 \sqcap 0 \square$ & I \\
\hline
\end{tabular}

\section{Figures}




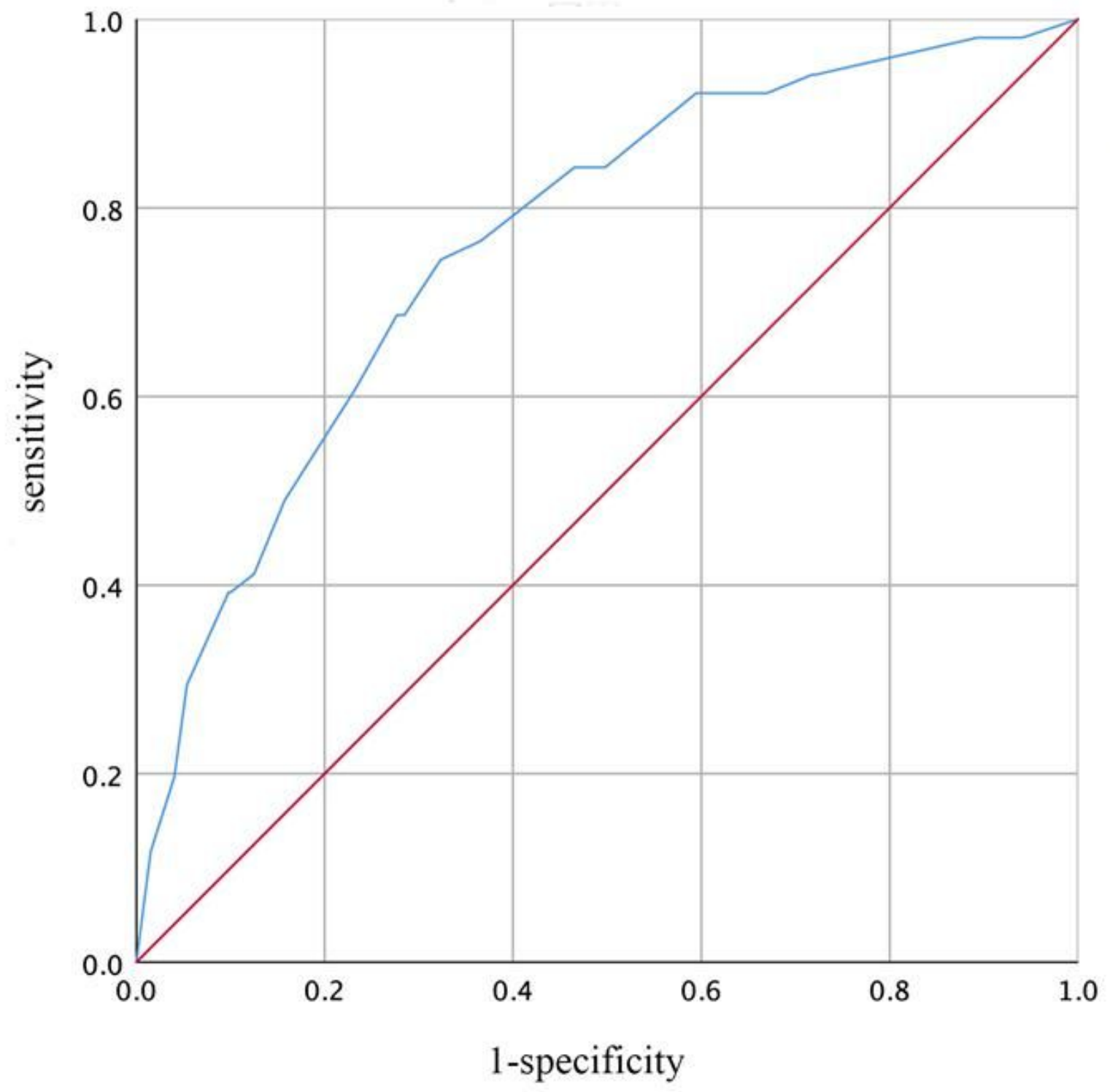

sensitivity

\section{Figure 1}

ROC curve for risk of post-ERCP pain without PEP 


Risk Factors
OR

Figure 2

Forrest plot for the factors involved in the risk of post-ERCP pain without PEP 